\title{
Effect of botanicals on collar rot of chickpea caused by Sclerotium rolfsii Sacc. in combination with Trichoderma harzianum
}

\author{
Suraj Kumar Patel, Siddarth N. Rahul ${ }^{\star}$ and Sushil Kumar Singh
}

Department of Plant Pathology, Acharya Narendra Deva University of Agriculture and Technology, Kumarganj, Ayodhya-224229, Uttar Pradesh India

\section{Article Info}

Article history

Received 9 October 2021

Revised 29 November 2021

Accepted 30 November 2021

Published Online 30 December 2021

Keywords
Botanicals
Trichoderma harzianum
Sclerotium rolfsii Sacc.
collar rot

collar rot

\begin{abstract}
In this study, the effect of different botanicals in combination with Trichoderma harzianum were used to observe plants mortality and yield affected by collar rot of chickpea. The effect of different treatments on germination at 20 days after sowing and vigour index 1 (germination $\times$ plant height), vigour index 2 (germination $\times$ dry weight ), 45, 60, 75 days after sowing (DAS) and also yield parameter like (yield per plot and yield in $\mathrm{q} / \mathrm{h}$ ) were evaluated at after harvesting of chickpea. Significant variant in germination of chickpea seeds were recorded under different treatments. The lowest germination was recorded in the control plot (T9) $(85.89 \%)$ and maximum in (T8) with (97.33\%) at 20 days after sowing. Highest vigour index 1 (2019.59) and vigour index 2 (147.94) were recorded in T8, maximum plant height in T8 (20.75, $25.25,33.38 \mathrm{~cm}$.), highest total number of branches per plant in T8 $(5.47,6.27,7.67)$, maximum fresh weight in $\mathrm{T} 8(6.42,17.50,20.72 \mathrm{gm}$.), maximum dry weight in $\mathrm{T} 8(1.52,4.26,5.09)$, minimum plant mortality in T8 $(3.55,7.47,14 \%)$ and maximum plant mortality in control $(9.73,15.07,21 \%)$ were recorded at 45, 60, 75 DAS, and maximum yield per plot in $\mathrm{T} 8(1.68 \mathrm{~kg})$ and also the yield parameter and plants mortality was best observed in T8 followed by in botanical T2 (Neem oil 2.5\%) with combination of Trichoderma harzianum, respectively.
\end{abstract}

\section{Introduction}

Chickpea (Cicer arietinum $\mathrm{L}$.) is, a self-pollinated, diploid $(2 \mathrm{n}=2 \mathrm{x}$ =16) annual legume of family Fabaceae and known as various names, viz., Gram, Bengal gram, Garbanzo and Egyption pea. It was first cultivated in south eastern region of the world, but now it is also cultivated in semi-arid regions (Agarwal et al., 2012). Pulses contain higher proportions of protein ( $17 \%-30 \%$ by dry weight) in comparison to other plant foods. With the protein, chickpea is a good source of carbohydrates has comparison to other pulses, according to Wallace et al. (2016). There are various biotic and abiotic factors that affect the production of the chickpea in the world as well as in India too. The biotic factor includes insect pests and a number of devastating diseases caused by fungi, bacteria, viruses, and nematodes. The fungal diseases such as Fusarium wilt (Fusarium oxysporium f.sp. ciceris), Ascochyta blight (Ascochyta rabiei), collar rot (Sclerotium rolfsii), Verticillium wilt (Verticillium dahliae), black root rot (Fusarium solani), Phytophthora root rot (Phytophthora megasparma) and seed rot (Aspergillus flavus), etc. Among all of the diseases collar rot disease, caused by Sclerotium rolfsii Sacc., is a serious threat to chickpea that may cause $55-95 \%$ mortality of the crop at seedling stage under favourable environmental conditions (Gurha and Dubey, 1982).

Corresponding author: Dr. Siddarth N. Rahul

Department of Plant Pathology, Acharya Narendra Deva University of Agriculture and Technology, Kumarganj, Ayodhya-224229, Uttar Pradesh India

E-mail: sagar4499@gmail.com

Tel.: +91-8795114474

Copyright $(\odot) 2021$ Ukaaz Publications. All rights reserved.

Email: ukaaz@yahoo.com; Website: www.ukaazpublications.com

\section{Materials and Methods}

\subsection{Preparation of botanicals}

Fresh parts of the test plants (Lantana camera, Eucalyptus spp. Ocimum sanctum and Azadirachta indica) were collected and washed thoroughly in clean water. Hundred grams of each washed samples were grinded in mortar and pestle by adding equal amount $(100 \mathrm{ml})$ of sterilized distilled water $(1: 1 \mathrm{~W} / \mathrm{V})$ and boiled at $80^{\circ} \mathrm{C}$ for $10 \mathrm{~min}$ in a hot water bath.The grinded material was filtered through muslin cloth followed by filtering through sterilized Whatman No. 1 filter paper and treated as standard 100 per cent plant extract (Nene and Thapliyal, 1982) and required concentrations of five per cent of each plant extract were prepared.

\subsection{Treatments details}

All the treatments were used as seed treatments. (T1) Seeds treated with combination of Trichoderma harzianum $(10 \mathrm{gm} / \mathrm{kg}$ seed) and Pseudomonas spp. (10 gm/kg seed). (T2) Seeds treated with combination of Trichoderma harzianum (10 gm $/ \mathrm{kg}$ seed) and Neem oil $(2.5 \%)$. (T3) Seed treated with combination of Trichoderma harzianum (10 gm/ $\mathrm{kg}$ seed) and Jeevamrit (5\%). (T4) Seed treated with combination of Trichoderma harzianum (10 gm/ $\mathrm{kg}$ seed) and Lentana camera extract (5\%). (T5) Seed treated with combination of Trichoderma harzianum (10 gm/kg seed) and Eucalyptus spp. extract (5\%). (T6) Seed treated with combination of Trichoderma harzianum $(10 \mathrm{gm} / \mathrm{kg}$ seed) and Ocimum sanctum extract (5\%). (T7) Seed treated with combination of Trichoderma harzianum $(10 \mathrm{gm} / \mathrm{kg}$ seed) and Neem leaf extract (5\%). (T8) Seed treated with combination of Trichoderma harzianum $(10 \mathrm{gm} / \mathrm{kg}$ seed $)$ and Carbendazim (3 gm/kg seed). 


\section{Results}

Results presented in (Table 1), indicated that the treatment tested against $S$. rolfsii has a positive effect in germination percentage as T8 give maximum germination percentage i.e., $(97.33 \%)$, maximum vigour index 1 and vigour index 2 in T8, i.e. (2019.57) (147.94) respectively, Observations presented in (Table 2), the data was recorded at different days after sowing, i.e. 45, 60, 75 (DAS). Maximum plant height was observed in T8, i.e. $(20.75 \mathrm{~cm})(25.25 \mathrm{~cm})(33.80 \mathrm{~cm})$, respectively, Total No. of branches per plant highest in T8, i.e. (5.47) (6.27) (7.67), respectively; highest total no. of pod/plant and seed index were recorded in T8, i.e. (53) (21.67 gm), respectively (Table 3). In Table 4, the highest fresh weight was recorded in T8 (6.42 gm) $(17.50 \mathrm{gm})(20.72 \mathrm{gm})$ and maximum dry weight in $\mathrm{T} 8(1.52 \mathrm{gm})(4.26$ gm) $(5.09 \mathrm{gm})$.

Table 1: Effect of different treatments on plant mortality and vigour index I and II of chickpe

\begin{tabular}{|c|c|c|c|c|c|c|}
\hline \multirow[t]{2}{*}{ Treatment } & \multirow{2}{*}{$\begin{array}{c}\text { Per cent } \\
\text { germination } \\
(\%)\end{array}$} & \multirow{2}{*}{$\begin{array}{r}\text { Vigour index } 1 \\
\text { (germination } \times \\
\text { plant length) }\end{array}$} & \multirow{2}{*}{$\begin{array}{l}\text { Vigour index } 2 \\
\text { (germination } \times \\
\text { dry weight) }\end{array}$} & \multicolumn{3}{|c|}{ Per cent mortality } \\
\hline & & & & 45 DAS & 60 DAS & 75 DAS \\
\hline T1 & 91.11 & 1589.86 & 104.77 & $7.03 \pm 0.15$ & $11.67 \pm 0.83$ & $17.67 \pm 0.76$ \\
\hline $\mathbf{T 2}$ & 95.11 & 1882.22 & 133.15 & $4.44 \pm 0.39$ & $8.17 \pm 0.76$ & $15.33 \pm 2.08$ \\
\hline T3 & 92.66 & 1652.12 & 109.33 & $5.90 \pm 0.62$ & $10.87 \pm 0.81$ & $17.27 \pm 0.64$ \\
\hline T4 & 89.77 & 1526.98 & 96.95 & $7.00 \pm 0.50$ & $12.50 \pm 0.50$ & $17.47 \pm 1.31$ \\
\hline T5 & 88.22 & 1458.27 & 76.75 & $7.80 \pm 0.48$ & $13.17 \pm 1.26$ & $17.50 \pm 0.70$ \\
\hline T6 & 93.88 & 1722.69 & 120.16 & $5.77 \pm 0.32$ & $10.20 \pm 0.36$ & $16.20 \pm 1.06$ \\
\hline $\mathbf{T} 7$ & 94.33 & 1780.95 & 123.57 & $5.30 \pm 0.36$ & $8.97 \pm 0.45$ & $15.50 \pm 1.32$ \\
\hline T8 & 97.33 & 2019.59 & 147.94 & $3.55 \pm 0.30$ & $7.47 \pm 0.55$ & $14.00 \pm 1.00$ \\
\hline T9 & 85.89 & 1313.25 & 67.85 & $9.73 \pm 0.31$ & $15.07 \pm 1.01$ & $21.00 \pm 1.00$ \\
\hline SE $(m)$ & 0.55 & 33.36 & 0.11 & 0.23 & 0.43 & 0.59 \\
\hline CD & 1.61 & 96.97 & 0.32 & 0.66 & 1.24 & 1.73 \\
\hline
\end{tabular}

(T1) Trichoderma harzianum (10 gm/kg seed) and Pseudomonas spp. (10 gm/kg seed). (T2) Trichoderma harzianum (10 gm/kg seed) and Neem oil (2.5\%). (T3) Trichoderma harzianum (10gm/kg seed) and Jeevamrit (5\%). (T4) Trichoderma harzianum (10 gm/kg seed) and Lentana camera extract (5\%). (T5) Trichoderma harzianum (10 gm/kg seed) and Eucalyptus spp. Extract (5\%). (T6) Trichoderma harzianum $(10 \mathrm{gm} / \mathrm{kg}$ seed) and Ocimum sanctum extract (5\%). (T7) Trichoderma harzianum $(10 \mathrm{gm} / \mathrm{kg}$ seed) and Neem leaf extract (5\%). (T8) Trichoderma harzianum (10 gm/kg seed) and Carbendazim (3 gm/kg seed), DAS-Days after showing, SE-Stander Error, CD-Critical Difference.

Table 2: Effect of different treatments on plant height and number of branches/plant

\begin{tabular}{|c|c|c|cc|c|c|}
\hline Treatment & \multicolumn{3}{|c|}{ Plant height (in cm.) } & \multicolumn{4}{c|}{ Total no of branches/plant } \\
\hline \multirow{2}{*}{ T1 } & $\mathbf{4 5}$ DAS & $\mathbf{6 0}$ DAS & $\mathbf{7 5}$ DAS & 45 DAS & 60 DAS & 75 DAS \\
\cline { 2 - 7 } T2 & $17.45 \pm 1.36$ & $22.62 \pm 1.46$ & $28.93 \pm 1.29$ & $4.27 \pm 0.42$ & $5.20 \pm 0.35$ & $5.33 \pm 0.23$ \\
T3 & $19.79 \pm 1.39$ & $24.87 \pm 0.98$ & $32.07 \pm 1.14$ & $5.07 \pm 0.90$ & $5.93 \pm 0.42$ & $6.33 \pm 0.23$ \\
T4 & $17.83 \pm 1.67$ & $23.60 \pm 1.34$ & $29.47 \pm 1.29$ & $4.33 \pm 0.50$ & $5.40 \pm 0.00$ & $5.47 \pm 0.12$ \\
T5 & $17.01 \pm 1.23$ & $22.59 \pm 0.95$ & $28.47 \pm 1.03$ & $4.20 \pm 0.53$ & $5.00 \pm 0.35$ & $5.27 \pm 0.12$ \\
T6 & $16.53 \pm 1.29$ & $22.05 \pm 1.50$ & $27.93 \pm 1.01$ & $4.13 \pm 0.46$ & $4.60 \pm 0.40$ & $4.87 \pm 0.23$ \\
T7 & $18.85 \pm 1.68$ & $23.79 \pm 1.51$ & $30.47 \pm 0.61$ & $4.47 \pm 0.42$ & $5.60 \pm 0.20$ & $5.73 \pm 0.31$ \\
T8 & $20.75 \pm 0.66$ & $25.25 \pm 1.10$ & $33.80 \pm 0.60$ & $5.47 \pm 0.64$ & $6.27 \pm 0.31$ & $7.67 \pm 0.58$ \\
T9 & $15.29 \pm 0.71$ & $20.94 \pm 0.52$ & $26.47 \pm 1.47$ & $3.40 \pm 0.53$ & $4.47 \pm 0.50$ & $4.60 \pm 0.20$ \\
SE(m) & $\mathbf{0 . 2 9}$ & $\mathbf{0 . 3 3}$ & $\mathbf{0 . 3 0}$ & $\mathbf{0 . 1 5}$ & $\mathbf{0 . 1 3}$ & $\mathbf{0 . 1 6}$ \\
CD & $\mathbf{0 . 8 4}$ & $\mathbf{0 . 9 6}$ & $\mathbf{0 . 8 7}$ & $\mathbf{0 . 4 3}$ & $\mathbf{0 . 3 8}$ & $\mathbf{0 . 4 8}$ \\
\hline
\end{tabular}

(T1) Trichoderma harzianum (10 gm/kg seed) and Pseudomonas spp. (10 gm/kg seed). (T2) Trichoderma harzianum (10 gm/kg seed) and Neem oil (2.5\%). (T3) Trichoderma harzianum (10 gm/kg seed) and Jeevamrit (5\%). (T4) Trichoderma harzianum (10 gm/ $/ \mathrm{kg} \mathrm{seed})$ and Lentana camera extract (5\%). (T5) Trichoderma harzianum (10 gm/kg seed) and Eucalyptus spp. extract (5\%). (T6) Trichoderma harzianum (10 gm/kg seed) and Ocimum sanctum extract (5\%). (T7) Trichoderma harzianum (10 gm/ $\mathrm{kg}$ seed) and Neem leaf extract (5\%). (T8) Trichoderma harzianum (10 gm/kg seed) and Carbendazim (3 gm/kg seed), DAS-Days after showing, SE-Stander Error, CD-Critical Difference. 
Table 3: Effect of different treatments on total number of pods/plant, seed index and yield

\begin{tabular}{|c|c|c|c|c|}
\hline Treatment & Total number of & Seed index (weight & \multicolumn{2}{|c|}{ Yield } \\
& pods/plant & /100 Seeds) in gm. & per plot (in $\mathbf{k g})$ & Q./ha \\
\hline T1 & $36.67 \pm 0.58$ & $17.50 \pm 1.50$ & $1.51 \pm 0.08$ & $17.26 \pm 0.73$ \\
T2 & $50.67 \pm 5.86$ & $20.67 \pm 1.53$ & $1.66 \pm 0.15$ & $18.70 \pm 0.61$ \\
T3 & $41.33 \pm 4.51$ & $18.67 \pm 1.53$ & $1.56 \pm 0.05$ & $17.59 \pm 0.73$ \\
T4 & $33.33 \pm 0.58$ & $17.43 \pm 1.44$ & $1.49 \pm 0.02$ & $16.85 \pm 0.85$ \\
T5 & $31.67 \pm 2.31$ & $17.33 \pm 2.08$ & $1.48 \pm 0.03$ & $16.33 \pm 0.40$ \\
T6 & $43.00 \pm 3.00$ & $19.17 \pm 1.53$ & $1.58 \pm 0.12$ & $17.88 \pm 0.73$ \\
T7 & $46.33 \pm 6.11$ & $19.67 \pm 1.53$ & $1.65 \pm 0.11$ & $18.36 \pm 0.50$ \\
T8 & $53.00 \pm 7.00$ & $21.67 \pm 1.53$ & $1.68 \pm 0.08$ & $19.29 \pm 1.22$ \\
T9 & $28.33 \pm 1.53$ & $15.30 \pm 0.61$ & $1.25 \pm 0.04$ & $15.29 \pm 0.84$ \\
SE(m) & $\mathbf{1 . 9 2}$ & $\mathbf{0 . 3 2}$ & $\mathbf{0 . 0 4}$ & $\mathbf{0 . 2 2}$ \\
CD & $\mathbf{5 . 5 8}$ & $\mathbf{0 . 9 4}$ & $\mathbf{0 . 1 2}$ & $\mathbf{0 . 6 3}$ \\
\hline
\end{tabular}

(T1) Trichoderma harzianum (10 gm/kg seed) and Pseudomonas spp. (10 gm/kg seed). (T2) Trichoderma harzianum (10 gm/ $\mathrm{kg}$ seed) and Neem oil (2.5\%). (T3) Trichoderma harzianum (10 gm/kg seed) and Jeevamrit (5\%). (T4) Trichoderma harzianum (10 gm/ $\mathrm{kg}$ seed) and Lentana camera extract (5\%). (T5) Trichoderma harzianum (10 gm/kg seed) and Eucalyptus spp. extract (5\%). (T6) Trichoderma harzianum (10 gm/kg seed) and Ocimum sanctum extract (5\%). (T7) Trichoderma harzianum (10 gm/kg seed) and Neem leaf extract (5\%). (T8) Trichoderma harzianum (10 gm/kg seed) and Carbendazim (3 gm/kg seed), DAS-Days after showing, SE-Stander Error, CD-Critical Difference.

Table 4: Effect of different treatments on Fresh and dry weight of plant

\begin{tabular}{|c|c|c|c|c|c|c|}
\hline \multirow{2}{*}{ Treatment } & \multicolumn{3}{|c|}{ Fresh weight (in gm.) } & \multicolumn{3}{c|}{ Dry weight (in gm.) } \\
\cline { 2 - 7 } & $\mathbf{4 5}$ DAS & $\mathbf{6 0}$ DAS & $\mathbf{7 5}$ DAS & 45 DAS & $\mathbf{6 0}$ DAS & $\mathbf{7 5}$ DAS \\
\hline T1 & $4.80 \pm 0.56$ & $13.92 \pm 0.48$ & $14.30 \pm 1.41$ & $1.15 \pm 0.17$ & $3.49 \pm 0.13$ & $3.76 \pm 0.35$ \\
T2 & $6.02 \pm 0.93$ & $15.65 \pm 0.08$ & $18.13 \pm 1.14$ & $1.40 \pm 0.17$ & $3.85 \pm 0.13$ & $4.59 \pm 0.22$ \\
T3 & $5.12 \pm 0.55$ & $14.30 \pm 0.72$ & $15.69 \pm 0.48$ & $1.18 \pm 0.19$ & $3.51 \pm 0.13$ & $3.93 \pm 0.18$ \\
T4 & $4.53 \pm 0.55$ & $13.44 \pm 0.38$ & $13.92 \pm 1.69$ & $1.08 \pm 0.09$ & $3.40 \pm 0.12$ & $3.61 \pm 0.41$ \\
T5 & $3.76 \pm 0.43$ & $12.53 \pm 0.76$ & $13.30 \pm 1.97$ & $0.87 \pm 0.05$ & $3.27 \pm 0.08$ & $3.40 \pm 0.41$ \\
T6 & $5.48 \pm 0.56$ & $14.83 \pm 0.54$ & $16.14 \pm 0.50$ & $1.28 \pm 0.16$ & $3.59 \pm 0.07$ & $4.17 \pm 0.11$ \\
T7 & $5.69 \pm 0.58$ & $14.99 \pm 0.52$ & $16.78 \pm 0.38$ & $1.31 \pm 0.17$ & $3.76 \pm 0.12$ & $4.26 \pm 0.03$ \\
T8 & $6.42 \pm 0.89$ & $17.50 \pm 1.44$ & $20.72 \pm 2.61$ & $1.52 \pm 0.15$ & $4.26 \pm 0.32$ & $5.09 \pm 0.51$ \\
T9 & $3.29 \pm 0.26$ & $10.59 \pm 0.32$ & $10.53 \pm 2.95$ & $0.79 \pm 0.05$ & $2.79 \pm 0.05$ & $2.61 \pm 0.63$ \\
SE(m) & $\mathbf{0 . 2 6}$ & $\mathbf{0 . 4 0}$ & $\mathbf{0 . 9 4}$ & $\mathbf{0 . 0 5}$ & $\mathbf{0 . 0 9}$ & $\mathbf{0 . 2 0}$ \\
CD & $\mathbf{0 . 7 7}$ & $\mathbf{1 . 1 6}$ & $\mathbf{2 . 7 3}$ & $\mathbf{0 . 1 4}$ & $\mathbf{0 . 2 6}$ & $\mathbf{0 . 5 8}$ \\
\hline
\end{tabular}

(T1) Trichoderma harzianum (10 gm/kg seed) and Pseudomonas spp. (10 gm/kg seed). (T2) Trichoderma harzianum (10 gm/kg seed) and Neem oil (2.5\%). (T3) Trichoderma harzianum (10 gm/ $\mathrm{kg}$ seed) and Jeevamrit (5\%). (T4) Trichoderma harzianum (10 gm/ $\mathrm{kg}$ seed) and Lentana camera extract (5\%). (T5) Trichoderma harzianum (10 gm/kg seed) and Eucalyptus spp. extract (5\%). (T6) Trichoderma harzianum (10 gm/ $/ \mathrm{kg}$ seed) and Ocimum sanctum extract (5\%). (T7) Trichoderma harzianum (10 gm/kg seed) and Neem leaf extract (5\%). (T8) Trichoderma harzianum (10 gm/ $\mathrm{kg}$ seed) and Carbendazim (3 gm/kg seed), DAS-Days after showing, (SE)-Stander Error, (CD) Critical Difference.

As shown in Table 2, chickpea yield was recorded in per plot (in $\mathrm{kg}$ ), significantly varied from one treatment to another. The yield of chickpea per plot ranges from $1.32 \mathrm{~kg}$ to $1.68 \mathrm{~kg}$. Table 4 and figure showed the highest grain yield $(\mathrm{kg} / \mathrm{plot})(1.68 \mathrm{~kg})$ in $(\mathrm{T} 8)$ and $(1.65$ $\mathrm{kg} / \mathrm{plot}$ ) in $\mathrm{T} 2$ were recorded best effective on grain yield over the control, i.e. T9 $(1.32 \mathrm{~kg})$, followed by $(1.65 \mathrm{~kg}), \mathrm{T} 7(1.61 \mathrm{~kg}), \mathrm{T} 6$, $(1.57 \mathrm{~kg}), \mathrm{T} 3(1.51 \mathrm{~kg})$ and $(1.48 \mathrm{~kg})$ in T5. Likewise yield q/h was recorded significantly varied from one treatment to another. Table 4 and Figure. showed the highest grain yield (q/h) (19.29 q), (T8) and $(18.70 \mathrm{q})$ in $\mathrm{T} 2$ were recorded best effective on grain yield over the control, i.e., T9 (15.29 q), followed by (18.36 q), T7 (17.88 q), T6 (17.59 q), T3 (17.26 q), T1 (16.85 q) and T4 (16.33 q) in T5, respectively.

The mortality presented in Table 2 showed that at 45,60 and 75 days after sowing (DAS) (Table 6 and Figure). At 45 days after sowing, maximum mortality $(9.73 \%)$ was observed in control plot (T9), which was statistically significant compared to other treatments. Minimum mortality $(3.55 \%)$ was recorded in the plot where seeds were treated with $\mathrm{T} 8$, followed by $\mathrm{T} 2(4.44 \%), \mathrm{T} 7$ 
(5.30\%), T6 (7.80\%). At 60 days after sowing, the Table 2 showed maximum mortality $(15.07 \%)$ was recorded in control plot T9, where minimum mortality $(7.47 \%)$ was found in the plot $\mathrm{T} 8$, followed by T2, T7, T6, T3 over the control as many worker like Pawar et al., (2014) Das et al. (2014) and Khan and Javaid (2015) also revealed that the chemicals have the significant effect on mortality and disease inhibition of chickpea. As shown in Table 1 at 75 days after sowing maximum mortality $(21 \%)$ was recorded in control plot T9. where minimum mortality $(14 \%)$ was found in the plot T8, followed by T2, T7, T6, T3,T1, T4 and T5.

\section{Discussion}

Many researchers like Khan et al. (2020) and Tewari and Mukhopadhyay (2000) used botanicals and bioagents as seed treatments increased seedling emergence. More et al., (2016) revealed that maximum seedling vigour index was recorded in Carbendazim followed by Trichoderma viride and Azadirachta indica in the requirement which support and shows the similarity observations are recorded in present investigation. Singh et al. (2018) revealed that the number of healthy pod per plant and seed index is similar as the present investigation. Tewari and Mukhopadhyay (2000) used botanicals as seed treatments and found affective in increases seedling emergence and grain yield. Many worker like Dutta et al. (1991) and the findings of Asgharian and Mayee (1991), Jhonson et al. (2008) was also similar as grain yield was increased while using of botanicals and bioagents. Kumar et al. (2008) also used bioagent and revealed that higher yield of chickpea.

Nagamma and Nagaraja (2015) revealed that the maximum inhibition of mycelial growth $(71.67 \%$ ) was noticed in Trichoderma harzianum which was followed by Trichoderma viride $(63.33 \%)$ under in vitro condition. Bhuiyan et al. (2012) also revealed that the bioagents have the significant effect on Sclerotium rolfsii and maximum inhibition was recorded and many worker like More et al. (2016), Khan et al. (2020) also revealed that the botanicals have the significant effect on mortality of chickpea plant. Prabhu (2003) revealed that the different systemic and non-systemic fungicides against Sclerotium rolfsii and reported $100 \%$ inhibition by carboxin, which was followed by carbendazim $(63 \%)+$ mancozeb $(12 \%)$ and propiconazole.

\section{Conclusion}

In the current investigation, it is concluded that application of T8 [Trichoderma herzianum $(10 \mathrm{~g} / \mathrm{kg}$ seed $)+$ Carbendazim $(3 \mathrm{~g} / \mathrm{kg}$ seed)] showed better performance in enhancing germination and reducing mortality percentage and appearance of the disease. This is also true that use of Trichoderma herzianum $(10 \mathrm{~g} / \mathrm{kg}$ seed $)+$ Carbendazim ( $3 \mathrm{~g} / \mathrm{kg}$ seed) promoted plant height, total number of branches/plant, total number of pod/plant reduced disease incidence and showed maximum grain yield of chickpea. In the botanicals, T2 [Trichoderma harzianum $(10 \mathrm{~g} / \mathrm{kg}$ seed $)+$ Neem oil $(2.5 \%)]$ was found to be the best in all prospects. In the remaining treatments, all were effectively controlling the disease and enhance the plant growth and production. For batter environment and to avoid hazardous effect of chemicals, the botanicals can be the alternative option to manage such kind of plant diseases.

\section{Conflict of interest}

The authors declare no conflicts of interest relevant to this article.

\section{References}

Agarwal, G.; Jhanwar, S.; Priya, P.; Singh, V.K. and Jain, M. (2012). Comparative analysis of kabuli chickpea transcriptome with desi and wild chickpea provides a rich resource for development of functional markers. Jour. of Plt. Path., 7:441-443.

Asghari, M.A and Mayee, C.D. (1991). Comparative efficacy of management practices on stem and pod rots of groundnut. In. Phytopath., 44: 328-332.

Ayock, R. (1966). Stem rot and other disease caused by Sclerotium rolfsii. North Carolina Agricultural Experiment Station. Tech. Bullt., 174202 .

Bhuiyan, M.A.H.B.; Rahman, M.T. and Bhuiyan, K.A. (2012). In vitro screening of fungicides and antagonists against Sclerotium rolfsii, Afr. Jour. of Biotech.11(82):14822-14827

Das, N.C.; Dutta, B.K. and Ray, D.C. (2014). Potential of some fungicides on the growth and dovelopement of Sclerotium rolfsii Sacc. In vitro. Inter. Jour. of Scie. and Rese. Publ., 4(12):ISSN 2250-3153.

Gupta, S.K. and Sharma, A. (2004). Symptomology and management of crown rot of (Sclerotium rolfsii) of French bean. Jour. of Myco. and Pl. Path., 34:820-823.

Gurha, S.N. and R.S. Dubey (1982). Occurrence of possible sources of resistance in chickpea (Cicer arietinum L.) against Sclerotium rolfsii Sacc. Madras Agri. Jour., 70:63-64

Harinath, N. (2000). Crossandra-A new host record for Sclerotium rolfsii. Ind. Phyto., 53:496-497.

Hind, T.S. (2005). Disease of field crop and their management, Daya Publishing House, New Delhi, 171 pp:171.

Jhonson, M.; Reddy, P.N and Reddy, D.R. (2008). Comparative efficacy of rhizosphere mycoflora, fungicides, insecticides and herbicides against groundnut stem rot caused by Sclerotium rolfsii. Ann. of Pl.Prote. Sci., 16(2):414-418.

Khan, I.H.and Javaid,A. (2015). Chemical control of collar rot disease of chickpea. Pak., Jour. of Phytopath. 27:(01)61-68.

More, P.S.; Parate, R.L. and Mairan, N.R. (2016). Evaluation of botanicals and bioagents to record the root, shoot length and vigour index of chickpea. Inter. Jour. of Pl. Prot., 9(2):483-488.

Nagamma, G. and Nagaraja, A. (2015). Efficacy of biocontrol agents against Sclerotium rolfsii causing collar rot disease of chickpea, under in vitro conditions. Inter. Jour. of P1. Prot., 8(2):222-227.

Narasimha, R.S.; Anahosur, K.H. and Srikant, K. (2004) Eco-friendly approaches for management of wilt of potato (Sclerotium rolfsii). Jour. of Myco. and Pl. Path., 34:327-329.

Nene, Y.L., Reddy; M.V., Haware; M.P., Ghanekar; A.M., Amin; K.S. Pande and Sharma, M. (2012) Field diagnosis of chickpea disease and their control. Information Bulletin No. 28 (Revised). Inter. Crop Rese. Inst. for the Semi-Arid Trop. Patancheru, A.P. 502 324, India, 2627 pp:2627.

Nyvall, R.F.(1989) Field Crop Disease Handbook, Second edition, Published by Van Nostrand Reinhold, New York, 817 pp:817.

Pawar, A.K.; Surywanshi, A.P.; Gawade, D.B.; Zagade, S.N and Wadje, A.G. (2014). Effects of organic amendments and fungicides on the survival of collar rot fungus of soybean incited by Sclerotium rolfsi. Afr. Jour. of Agri. Res., 9(27):2124-2131. 
Prabhu, H.V. (2003). Studies on collar rot of soybean caused Sclerotium rolfsii Sacc. M.Sc. (Agri.) Thesis, University of Agricultural Sciences. Dharwad.

Rajalakshmi (2002) Studies on variability among the isolates of Sclerotium rolfsii. M. Sc.(Ag) Thesis, Acharya N. G. Ranga Agricultural University, Hyderabad, Andhra Pradesh.

Rakholiya, K.B. and Jadeja, K.B. (2011). Morphological diversity of Sclerotium rolfsii caused and pod rot of groundnut. Jour. of Myco. and Pl. Path., 41(4):500-504.

Ramesh, A.; Gupta, O. and Mishra M. (2014) Technique for screening of chickpea genotype against collar rot, its management through host plant rasistance and fungicides. Leg. Res., 37(1):110-114.
Reddi, M.K.; Santhoshi, M.V.M.; Krishna, T.G. and Reddy, K.R. (2014) Cultural and morphological variability Sclerotium rolfsii isolates infecting ground nut and its reaction to some fungicides. Inter. Jou. of Currt. Microb. and App. Sci., 3(10):553-561.

Shivani, B.R.; Dubey, R.C. and Maheshwari, D.K. (2005) Enhancement of plant growth and suppression of collar rot of sunflower caused by Sclerotium rolfsii through Pseudomonas fluorescens. In: Phytopath., 58(1):17-42.

Tewari, A.K and Mukhopadhyay, A.N. (2000). Management of chickpea root rot and collar rot by integration of biological and chemical seed treatment. In: Phytopath., 56(1):39-42.

Wallace, T.C.; Murray, R. and Zelman, K.M. (2016). The nutritional value and health benefits of chickpeas and hummus. Nutrients, 8(12):E766. 